\title{
A Diabetic Case with Hemoglobin J-Meerut and Low $\mathrm{HbA}_{1 \mathrm{C}}$ Levels
}

\author{
Mitsunori Yagame, Kiichiro Jinde, Daisuke Suzuki, Noboru Saotome, Hideo Takano, \\ Ryoji Tanabe, Haruhiro Sato, Kiyoshi Kurokawa, Hideto Sakai, Mitsunori Matsumae*, \\ Hiroyasu MASE** and Teruo HARANO***
}

\begin{abstract}
A diabetic patient with hemoglobin $(\mathrm{Hb}) \mathrm{J}$-Meerut and low $\mathrm{HbA}_{1 \mathrm{C}}$ levels is reported. An automatic glycohemoglobin analyzer used for the determination of $\mathrm{HbA}_{1 \mathrm{C}}$ revealed an abnormal peak of the peripheral blood obtained from a Japanese female with diabetes. She showed a lower $\mathrm{HbA}_{1 \mathrm{C}}$ level (3.7\%) than expected from her fasting plasma glucose $(172 \mathrm{mg} / \mathrm{dl})$. High performance liquid chromatography and isoelectric focusing indicated that her abnormal hemoglobin was $\mathrm{Hb}$ $\mathrm{J}$-Meerut $[\alpha 120(\mathrm{H3}) \mathrm{Ala} \rightarrow \mathrm{Glu}]$ and it accounted for $28.3 \%$ of the total hemoglobin. Abnormal hemoglobinemia should be considered when a major discrepancy between the levels of $\mathrm{HbA}_{1 \mathrm{C}}$ and fasting plasma glucose is observed.

(Internal Medicine 36: 351-356, 1997)
\end{abstract}

Key words: 1,5 anhydroglucitol, fructosamine, abnormal hemoglobin

\section{Introduction}

Abnormal hemoglobin $(\mathrm{Hb})$ which produces no hematological symptoms is rarely detected. However, diabetes mellitus provides an opportunity for the discovery of abnormal $\mathrm{Hb}$ because the determination of glycated hemoglobin $\left(\mathrm{HbA}_{1 \mathrm{C}}\right)$ is a good index of the blood glucose level over the previous few months (1-4). We report a diabetic patient with $\mathrm{Hb} \mathrm{J}$-Meerut (5-9), who showed a low level of $\mathrm{HbA}_{1 \mathrm{C}}$ in spite of a high concurrent level of plasma glucose.

For editorial comment, see p 321.

The purpose of this report is to describe this patient with abnormal $\mathrm{Hb}$ and to draw attention to the presence of abnormal $\mathrm{Hb}$ when a diabetic patient shows a discrepancy between levels of HbAlc and plasma glucose.

\section{Case Report}

A 48-year-old female who was living in Kanagawa Prefecture was admitted to Tokai University Hospital because of a brain abscess in the left lateral lobe caused by $\alpha$ hemolytic streptococcus on October 13, 1994. She had been taking an oral hypoglycemic drug from a local physician for non-insulindependent diabetes mellitus (NIDDM) since 1984, and was referred to us for evaluation and control of diabetes mellitus. She never complained of thirst, polyuria, blurred vision or numbness in the extremities. At the age of 20, she had an operation for pulmonary valve stenosis. Her father and paternal grandfather had diabetes mellitus, but there have been no diabetics on her mother's side. No consanguineous marriage was noted. Her height was $160 \mathrm{~cm}$, body weight $50.0 \mathrm{~kg}$, blood pressure $110 / 70 \mathrm{mmHg}$ and pulse rate $64 / \mathrm{min}$. On physical examination, she showed no particular findings except right hemiparesis with facial nerve palsy and dysarthria.

\section{Laboratory findings}

Laboratory findings on admission are shown in Table 1. A slightly elevated white blood cell count $(9,200 / \mu \mathrm{l}$; segment: $86.5 \%)$ and a slightly elevated C-reactive protein $(0.31 \mathrm{mg} / \mathrm{dl})$ value were noted. Fasting plasma glucose (FPG) was $180 \mathrm{mg} /$ $\mathrm{dl}, \mathrm{HbA}_{\mathrm{IC}} 12.4 \%$, total cholesterol $247 \mathrm{mg} / \mathrm{dl}$ and triglyceride $91 \mathrm{mg} / \mathrm{dl}$. Urinalysis showed $3(+)$ glucose $(159.3 \mathrm{~g} /$ day $)$ and negative proteinuria. Urinary C-peptide level was $46.5 \mu \mathrm{g} / \mathrm{day}$. Based on these findings, she was diagnosed as having NIDDM.

From the Division of Nephrology and Metabolısm, Department of Internal Medicıne, *Department of Neurosurgery and **Department of Clınıcal Laboratory, Tokaı Unıversity School of Medıcıne, Isehara and ***Department of Bıchemıstry, Kawasakı Medıcal School, Kurashıkı

Received for publication March 19, 1996; Accepted for publication March 17, 1997

Reprint requests should be addressed to Dr Mitsunorı Yagame, the Division of Nephrology and Metabolısm, Department of Internal Medicine, Toka1 Unıversity School of Medicine, Bohseıdaı, Isehara, Kanagawa 259-11 
YAGAME et al

Table 1. Laboratory Data on Admission

\begin{tabular}{|c|c|c|c|}
\hline \multicolumn{2}{|l|}{ Complete blood count } & \multicolumn{2}{|l|}{ Serum test } \\
\hline White blood cell & $9,200 / \mu 1$ & $\operatorname{IgG}$ & $944 \mathrm{mg} / \mathrm{dl}$ \\
\hline (Segm & lent: $86.5 \%$ ) & $\operatorname{IgA}$ & $206 \mathrm{mg} / \mathrm{dl}$ \\
\hline Red blood cell & $423 \times 10^{4} / \mu \mathrm{l}$ & $\operatorname{IgM}$ & $99 \mathrm{mg} / \mathrm{dl}$ \\
\hline Hemoglobin & $14.2 \mathrm{~g} / \mathrm{dl}$ & $\mathrm{C}$ reactive protein & $0.31 \mathrm{mg} / \mathrm{dl}$ \\
\hline Hematocrit & $39.6 \%$ & & \\
\hline Platelet & $25.4 \times 10^{4} / \mu 1$ & Hemoglobin $\mathrm{A}_{1 \mathrm{C}}$ & $12.4 \%$ \\
\hline \multirow[t]{2}{*}{ Reticulocyte } & $33 \%$ & & \\
\hline & & Urinalysis & \\
\hline Blood chemistry & & Glucose & $(+++)$ \\
\hline Fasting plasma glucose & $180 \mathrm{mg} / \mathrm{dl}$ & & $159.3 \mathrm{~g} /$ day \\
\hline Creatinine & $0.6 \mathrm{mg} / \mathrm{dl}$ & Protein & $(-)$ \\
\hline Blood urea nitrogen & $17 \mathrm{mg} / \mathrm{dl}$ & & $0.11 \mathrm{~g} / \mathrm{day}$ \\
\hline Uric acid & $3.4 \mathrm{mg} / \mathrm{dl}$ & Occult blood & $(-)$ \\
\hline Total protein & $6.7 \mathrm{~g} / \mathrm{dl}$ & Urinary C-peptide & $46.5 \mu \mathrm{g} /$ day \\
\hline Albumin & $3.9 \mathrm{~g} / \mathrm{dl}$ & Urinary albumin & $38.5 \mu \mathrm{g} / \mathrm{min}$ \\
\hline Aspartate aminotransferase & $6 \mathrm{U} / l$ & & \\
\hline Aranine aminotransferase & $5 \mathrm{U} / l$ & Glomerular filtration rate & $97 \mathrm{ml} / \mathrm{min}$ \\
\hline Total bilirubin & $0.6 \mathrm{mg} / \mathrm{dl}$ & & \\
\hline Low density lipoprotein & $227 \mathrm{U} / l$ & & \\
\hline$\gamma$-glutamyl transpeptidase & $12 \mathrm{U} / l$ & & \\
\hline Alkaline phosphatase & $168 \mathrm{U} / l$ & & \\
\hline $\mathrm{Na}$ & $134 \mathrm{mEq} / \mathrm{l}$ & & \\
\hline $\mathrm{K}$ & $4.7 \mathrm{mEq} / \mathrm{l}$ & & \\
\hline $\mathrm{Cl}$ & $93 \mathrm{mEq} / \mathrm{l}$ & & \\
\hline Total cholesterol & $247 \mathrm{mg} / \mathrm{dl}$ & & \\
\hline Triglyceride & $91 \mathrm{mg} / \mathrm{dl}$ & & \\
\hline
\end{tabular}

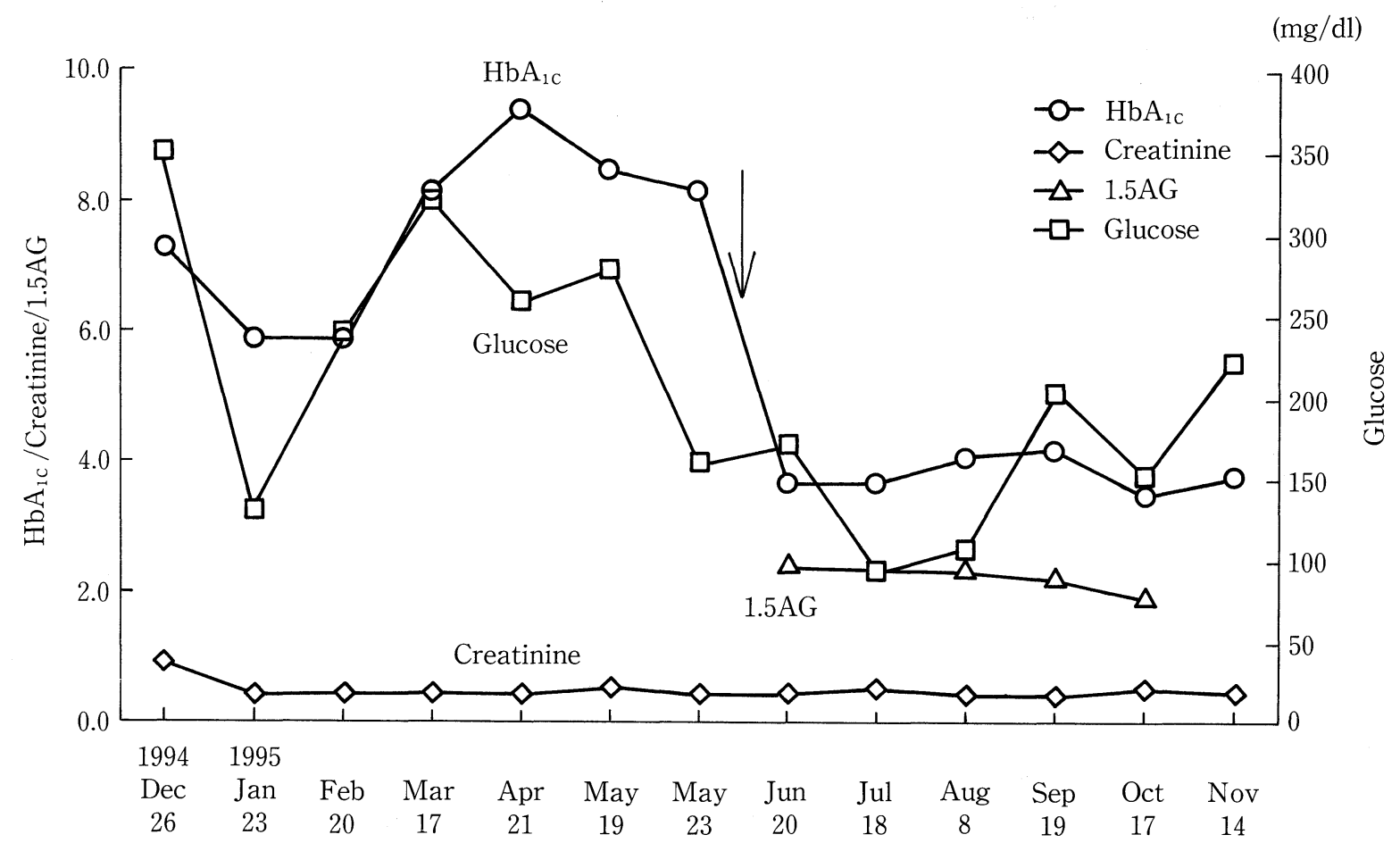

Figure 1. Clinical course of the patient from December 1994 to November 1995. "Glucose" means fasting plasma glucose and " $1,5 \mathrm{AG}$ " indicates plasma 1,5 anhydroglucitol. The method for measurement of $\mathrm{Hb}_{1 \mathrm{C}}$ was changed from June 1, 1995 (arrow). 


\section{Clinical course}

She had burr hole opening and irrigation of the brain abscess on October 26, 1994. After discharge on December 15, 1994, she was treated by calorie restriction $(1,440 \mathrm{kcal} /$ day $)$ and an oral hypoglycemic drug (glibenclamide, $5 \mathrm{mg} /$ day) for treatment of diabetes mellitus. The level of $\mathrm{HbA}_{1 \mathrm{C}}$ was 8.2 to $9.4 \%$ and that of FPG from 200 to $300 \mathrm{mg} / \mathrm{dl}$ in the outpatient clinic (Fig. 1). However, the levels of $\mathrm{HbA}_{1 \mathrm{C}}$ suddenly fell to $3.7 \%$ on June 20, 1995, with relatively improved glycemic control (FPG: $172 \mathrm{mg} / \mathrm{dl}$ ), high level of fructosamine (365 $\mu \mathrm{mol} / \mathrm{l}$, normal range: $205-285 \mu \mathrm{mol} / l$ ) and a low level of plasma 1,5 anhydroglucitol $(2.5 \mu \mathrm{g} / \mathrm{ml}$, normal range: $12-29 \mu \mathrm{g} / \mathrm{ml})$.

\section{Measurement of $\mathrm{HbA1c}$}

$\mathrm{HbA}_{1 \mathrm{C}}$ was measured by high performance liquid chromatography (HPLC) using HLC-723GHbIII (Tosoh, Tokyo) in our hospital until May 31, 1995. Samples were incubated with hemolytic solution $\mathrm{C}(\mathrm{pH} 7.4)$ at $45^{\circ} \mathrm{C}$ for 3.5 minutes before analysis. Hemolytic solution $\mathrm{C}$ did not eliminate unstable $\mathrm{HbA}_{1 \mathrm{C}}$ from these samples. This method included unstable $\mathrm{Hb}$ fraction separation, so that the normal range of $\mathrm{HbA}_{1 \mathrm{C}}$ by this method was relatively high at 5.2 to $6.7 \%$. For a precise analysis, we performed the HPLC for 5 minutes. The elution pattern of hemoglobin of a control patient is shown in Fig. 2. The level of stable $\mathrm{HbA}_{1 \mathrm{C}}$ (peak A1) was $4.6 \%$ and that of peak A2 which was composed of unstable $\mathrm{HbA}_{1 \mathrm{C}}$ and other unknown substances was $2.2 \%$.

The elution pattern of hemoglobin of this patient is shown in Fig. 3. The level of stable $\mathrm{HbA}_{1 \mathrm{C}}$ (peak A1) was 6.4\%, and there were two peaks in the A2 position in Fig. 2. The first such peak (peak A2) was recognized as the unstable $\mathrm{HbA}_{1 \mathrm{C}}$ and other unknown substances because this peak was decreased from $2.0 \%$ to $1.2 \%$ in Fig. 4 (see below). The second peak was also recognized to be abnormal hemoglobin.

According to the recommendation of the Japan Diabetes Society, the measurement of $\mathrm{HbA}_{1 \mathrm{C}}$ was changed to HPLC using HLC-723GHbIIIs (Tosoh) from June 1, 1995. Samples were incubated with hemolytic solution $\mathrm{E}(\mathrm{pH} 5.8)$ at $50^{\circ} \mathrm{C}$ for 1.5 minutes before analysis. Hemolytic solution $\mathrm{E}$ eliminated the unstable $\mathrm{HbA}_{1 \mathrm{C}}$ from the samples. The new method excluded unstable $\mathrm{Hb}$ fraction separation, and the normal range of $\mathrm{HbA}_{1 \mathrm{C}}$ was $4.3-5.8 \%$. The elution pattern of hemoglobin of this patient using solution $\mathrm{E}$ is shown in Fig. 4. Peak $\mathrm{J}$ was not changed even after using solution $\mathrm{E}$ (from $2.5 \%$ to $2.6 \%$ ).

$\begin{array}{rrrr}\text { Name } & \% & \text { Time } & \text { Area } \\ & & & \\ \text { FP } & 0.0 & 0.3 & 21.99 \\ \text { A1A } & 0.8 & 0.6 & 52.09 \\ \text { A1B } & 0.6 & 1.0 & 36.73 \\ \text { F } & 1.6 & 1.5 & 100.00 \\ \text { LA1C } & 2.2 & 2.0 & 133.30 \\ \text { S-A1C } & 4.6 & 2.5 & 285.68 \\ \text { A0 } & 90.2 & 3.3 & 5,578.39\end{array}$

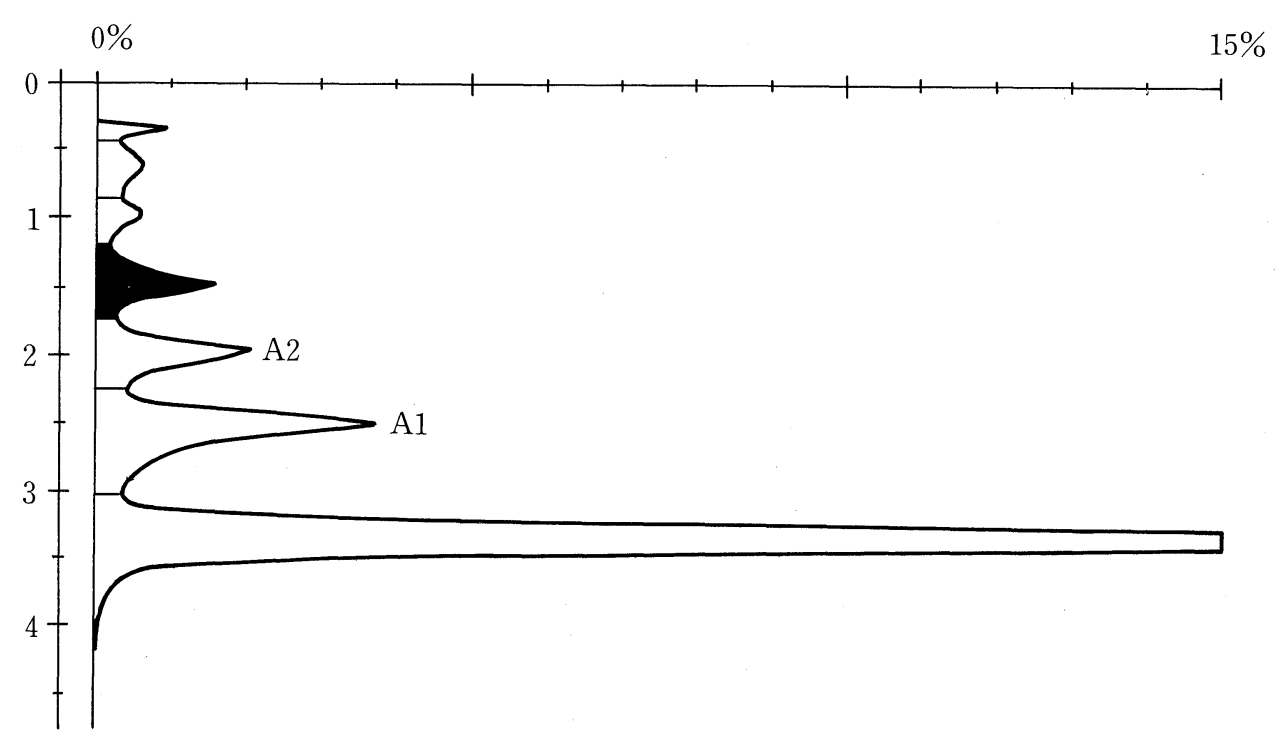

Figure 2. Elution pattern of hemoglobin of a control patient on HPLC (HLC-723GHbIII) using hemolytic solution $\mathrm{C}$ for 5 minutes. The level of stable $\mathrm{HbA}_{1 \mathrm{C}}$ (peak $\mathrm{A1}$ ) was estimated to be 4.6\%. Peak $\mathrm{A} 2$ included unstable $\mathrm{HbA}_{1 \mathrm{C}}$ and was $2.2 \%$. 


$\begin{array}{rrrr}\text { Name } & \% & \text { Time } & \text { Area } \\ \text { FP } & 0.0 & 0.3 & \\ \text { A1A } & 0.5 & 0.6 & 33.70 \\ \text { A1B } & 0.6 & 0.7 & 38.31 \\ \text { P00 } & 0.5 & 1.0 & 31.37 \\ \text { P01 } & 0.4 & 1.4 & 26.65 \\ \text { F } & 1.3 & 1.7 & 78.38 \\ \text { LA1C } & 2.0 & 1.9 & 126.42 \\ \text { J } & 2.5 & 2.1 & 395.22 \\ \text { S-A1C } & 6.4 & 2.5 & 5,303.06 \\ \text { A0 } & 85.7 & 3.3 & \end{array}$

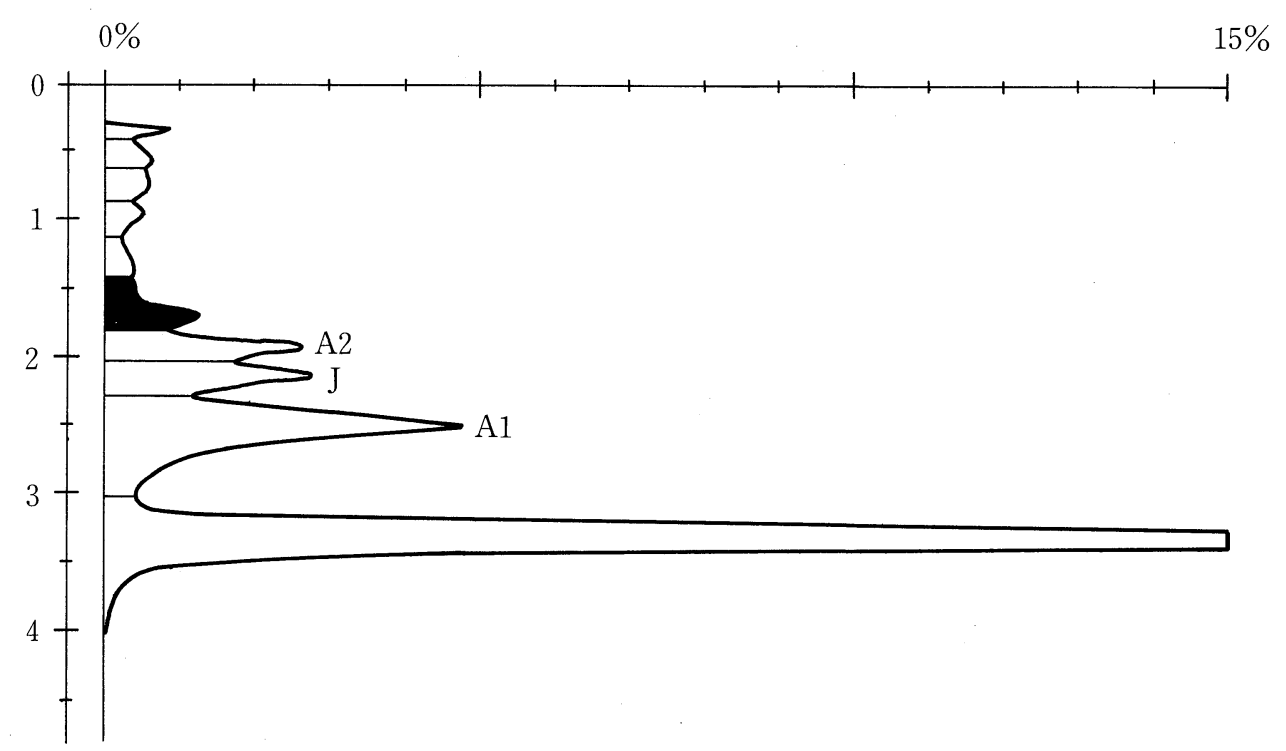

Figure 3. Elution pattern of hemoglobin of the present patient on HPLC (HLC-723GHbIII) using hemolytic solution $\mathrm{C}$ for 5 minutes. The amount of stable $\mathrm{HbA}_{1 \mathrm{C}}$ (peak $\mathrm{A1}$ ) was estimated to be $6.4 \%$. Peak $\mathrm{A} 2$ included unstable $\mathrm{HbA}_{1 \mathrm{C}}$ and was $2.0 \%$. The abnormal $\mathrm{Hb}$ (Hb J-Meerut) was found as peak $J$ and it was estimated to be $2.5 \%$. The blood sample was obtained in August, 1996.

\section{Analysis of abnormal $\mathrm{Hb}$}

Quantitative analyses of abnormal $\mathrm{Hb}$ by isoelectric focusing (IEF), HPLC and the isopropanol precipitation test were performed at the Department of Biochemistry, Kawasaki Medical School. The results showed that the abnormal $\mathrm{Hb}$ made up $28.3 \%$ of the total $\mathrm{Hb}$. Structural analysis of the abnormal $\mathrm{Hb}$ was carried out as described previously (10), and revealed that it was an $\alpha$ chain variant, namely $\mathrm{Hb} \mathrm{J}$-Meerut (or $\mathrm{Hb} \mathrm{J}$ Birmingham) [ $\alpha 120(\mathrm{H} 3) \mathrm{Ala} \rightarrow \mathrm{Glu}](5-9)$. The results of an isopropanol precipitation test were negative, and this abnormal $\mathrm{Hb}$ did not show any instability or dysfunction.

\section{Discussion}

This study reported a diabetic patient with $\mathrm{Hb} \mathrm{J}$-Meerut (or $\mathrm{Hb}$ J-Birmingham) and a low $\mathrm{HbA}_{\mathrm{IC}}$ value. This variant of hemoglobin has been described previously in two sisters from Meerut, India (5), in two brothers from Bangladesh living in Birmingham, England (6), in two unrelated Japanese families
$(7,8)$ and in one family from Ankara, Turkey $(9)$.

Approximately 500 kinds of abnormal $\mathrm{Hb}$ have been reported all over the world (11). One-third of these patients showed some hematological symptoms, such as cyanosis or polycythemia, but the remaining two-thirds showed no hematological symptoms. In the latter group, the abnormal $\mathrm{Hb}$ revealed a deviation in electric charge caused by the replacement of amino acids, and thus it was discovered when determination of $\mathrm{HbA}_{1 \mathrm{C}}$ by HPLC was performed in diabetic patients. Several diabetic patients who showed lower levels of $\mathrm{HbA}_{1 \mathrm{C}}$ than expected from the level of fasting plasma glucose were reported (12-19) (Table 2). In contrast, some diabetic patients showing higher levels of $\mathrm{HbA}_{1 \mathrm{C}}$ than expected from the level of fasting plasma glucose were also reported (20-25).

In the present case, it appeared that the $\mathrm{HbA}_{1 \mathrm{C}}$ value was higher than expected from her diabetic condition before May 31,1995 . The levels of $\mathrm{HbA}_{1 \mathrm{C}}$ suddenly decreased by about $5 \%$ on June 20,1995 . The level of unstable $\mathrm{HbA}_{1 \mathrm{C}}$ was about $0.8 \%$ ( $11 \%$ of total $\mathrm{HbA}_{1 \mathrm{C}}$ ) and that of abnormal $\mathrm{Hb}(\mathrm{Hb} \mathrm{J}$-Meerut) 
A Diabetic Case with $\mathrm{Hb}$ J-Meerut

$\begin{array}{rccc}\text { Name } & \% & \text { Time } & \text { Area } \\ \text { FP } & 0.0 & 0.4 & 26.68 \\ \text { A1A } & 1.3 & 0.6 & 70.95 \\ \text { A1B } & 0.4 & 0.9 & 22.15 \\ \text { P00 } & 0.4 & 1.3 & 22.08 \\ \text { F } & 0.8 & 1.7 & 45.41 \\ \text { LA1C } & 1.2 & 1.9 & 66.76 \\ \text { J } & 2.6 & 2.1 & 141.78 \\ \text { S-A1C } & 6.3 & 2.5 & 347.67 \\ \text { A0 } & 87.1 & 3.3 & 4,823.65\end{array}$

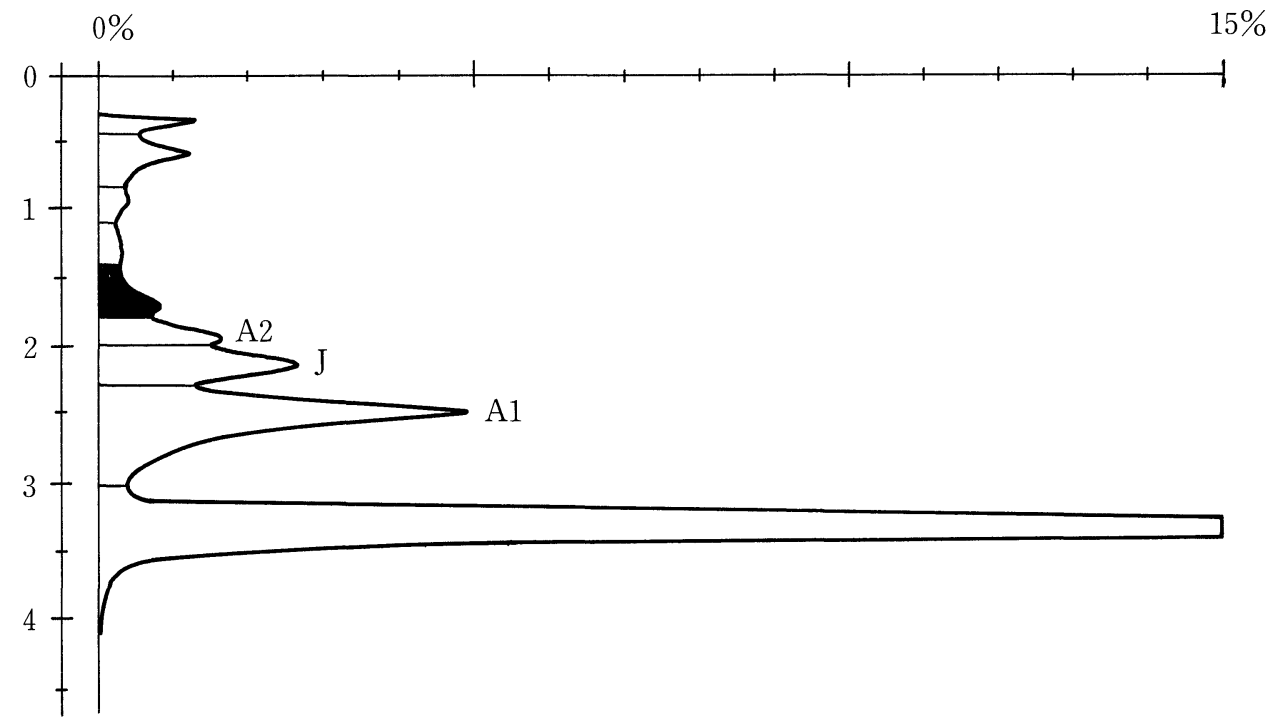

Figure 4. Elution pattern of hemoglobin of this patient on HPLC (HLC-723GHbIIIs) using hemolytic solution $\mathrm{E}$ after excluding unstable $\mathrm{HbA}_{1 \mathrm{C}}$ for 5 minutes. The level of stable $\mathrm{HbA}_{1 \mathrm{C}}$ (peak A1) was estimated to be $6.3 \%$ and peak A2 was $1.2 \%$. The abnormal $\mathrm{Hb}$ (Hb JMeerut) was found as peak $J$ and was estimated to be $2.6 \%$. The blood sample was obtained in August, 1996.

Table 2. Cases of Abnormal $\mathrm{Hb}$ with Lower $\mathrm{HbA}_{1 \mathrm{C}}$ Level

\begin{tabular}{|c|c|c|c|c|c|c|c|c|c|c|}
\hline Abnormal Hb & $\begin{array}{l}\text { Amino acid } \\
\text { abnormality }\end{array}$ & Age & Sex & Diag. & $\begin{array}{c}\text { FBS } \\
(\mathrm{mg} / \mathrm{dl})\end{array}$ & $\begin{array}{c}\mathrm{HbA}_{1} \\
(\%)\end{array}$ & $\begin{array}{c}\mathrm{HbA}_{1 \mathrm{C}} \\
(\%)\end{array}$ & $\begin{array}{l}1,5-\mathrm{AG} \\
(\mu \mathrm{g} / \mathrm{ml})\end{array}$ & $\begin{array}{c}\text { FRA } \\
(\mu \mathrm{mol} / l)\end{array}$ & $\begin{array}{l}\text { Ref. } \\
\text { no. }\end{array}$ \\
\hline \multirow[t]{2}{*}{ Hb Himeji } & \multirow[t]{2}{*}{$\beta 140 \mathrm{Ala} \rightarrow \mathrm{Asp}$} & 52 & M & \multirow[t]{2}{*}{ NIDDM } & 186 & \multirow[t]{2}{*}{24.9} & 5.1 & & & 12 \\
\hline & & 31 & $\mathrm{~F}$ & & 106 & & 2.0 & & & 13 \\
\hline Hb Takamatsu & $\beta 120$ Lys $\rightarrow$ Gln & 70 & M & NIDDM & 162 & 9.2 & 3.6 & & & 14 \\
\hline \multirow[t]{2}{*}{$\mathrm{Hb}$ Camden } & \multirow[t]{2}{*}{$\beta 131 \mathrm{Gln} \rightarrow \mathrm{Glu}$} & 34 & M & $\mathrm{DM}$ & 379 & 17 & & & & 15 \\
\hline & & 75 & $\mathrm{~F}$ & $\mathrm{DM}$ & 343 & 22.4 & 7.6 & & & 16 \\
\hline \multirow[t]{3}{*}{ Hb Riyadh } & \multirow[t]{3}{*}{$\beta 120$ Lys $\rightarrow$ Asn } & 52 & $\mathrm{~F}$ & DM & 120 & 11.3 & 3.1 & & & 17 \\
\hline & & 55 & M & NIDDM & 136 & & 3.5 & & & 18 \\
\hline & & 74 & M & NIDDM & 219 & & 3.0 & & & 19 \\
\hline Hb J-Meerut & $\alpha 120(\mathrm{H} 3) \mathrm{Ala} \rightarrow \mathrm{Glu}$ & 48 & $\mathrm{~F}$ & NIDDM & 172 & 4.7 & 3.7 & 2.5 & 365 & $\mathrm{PC}$ \\
\hline
\end{tabular}

FBS: fastıng blood sugar, 1,5-AG: 1,5-anhydroglucitol, FRA: fructosamine, PC: present case. 


\section{YAGAME et al}

was 2.5 to $2.6 \%$ in Figs. 3 and 4 . The reasons for this $5 \%$ decrease were considered to be the removal of the unstable $\mathrm{HbA}_{1 \mathrm{C}}$ and $\mathrm{Hb} \mathrm{J}-$ Meerut after using hemolytic solution $\mathrm{E}$, and improved glycemic control (Fig. 1).

Automatic determination of $\mathrm{HbA}_{1 \mathrm{C}}$ using HPLC is becoming popular as a means of evaluation of metabolic control in diabetic patients and in health examinations. The presence of abnormal $\mathrm{Hb}$ should be suspected when the level of $\mathrm{HbA}_{1 \mathrm{C}}$ is higher or lower than expected from the level of plasma glucose.

\section{References}

1) Bunn HF, Haney DN, Kamın S, Gabbay KH, Gallop PM. The bıosynthesis of human hemoglobin A1c; slow glycosylation of hemoglobin in vivo J Clin Invest 57: 1652, 1976.

2) Koenıg RJ, Peterson CM, Kılo C, Ceramı A, Willıamson JR. Hemoglobın Alc as an indicator of the degree of glucose intolerance in diabetes. Diabetes 25: 230, 1976.

3) Bunn HF. Evaluation of glycosylated hemoglobın in diabetıc patıents. Diabetes 30: 613, 1981

4) Mayer TK, Freedman ZR. Protein glycosylation in diabetes mellitus; a review of laboratory measurements and of their clinıcal utılity. Clın Chım Acta 127: 147, 1983.

5) Blackwell RQ, Wong HB, Wang CL, Weng MI, Liu CS. Hemoglobin J Meerut. $\alpha 120$ Ala $\rightarrow$ Glu. Biochım. Biophys Acta 351: 7, 1974.

6) Kamuzora H, Lehmann H, Griffiths KD, Mann JR, Raine DN. A new haemoglobın varıant haemoglobın J Bırmıngham $\alpha 120$ (H3) Ala $\rightarrow$ Glu. Ann Clin Biochem 11: 53, 1974

7) Harano $\mathrm{T}$, Harano K, Imal K, et al. Hb J-Meerut $[\alpha 120(\mathrm{H} 3) \mathrm{Ala} \rightarrow \mathrm{Glu}]$ found in a Japanese family. Hemoglobin 13: 169, 1989.

8) Takemura Y, Ikeda Y, Toyama K, et al. A case of abnormal hemoglobınemı. Nihon Ketsuekı Gakkaı Zasshı (Acta Haematol Jpn), 42: 142, 1979 (in Japanese)

9) Yalcın A, Avcu F, Beyan C, Gurgey A, Ural AU. A case of Hb J-Meerut (or Hb J-Bırmıngham) [ $\alpha 120(\mathrm{H} 3)$ Ala $\rightarrow$ Glu] Hemoglobin 18: 433, 1994.

10) Harano $T$, Harano $K$, Ueda $S$ Hb Owarı $[\alpha 121(\mathrm{H} 4) \mathrm{Val} \rightarrow$ Met $]$ : a new hemoglobın variant with a neutral-to-neutral amino acid substitution detected by isoelectric focusing. Hemoglobin 10: 127, 1986.

11) International Hemoglobın Information Center IHIC varıants list. Hemoglobin 12: 209, 1988.

12) Ohba Y, Mıyajı T, Murakamı M, et al. Hb Hımejı or $\beta 140(\mathrm{H} 18)$ Ala $\rightarrow$ Asp. A slightly unstable hemoglobin with increased $\beta$ N-terminal glycatıon. Hemoglobin 10: 109, 1986

13) Abe F, Yoshıoka H, Mizuno A, et al A famıly of hemoglobinopathy detected with high performance liquid chromatography. Rinsho Byorı (Japanese Journal of Clinical Pathology) 35: 797, 1987 (in Japanese).

14) Tanaka Y, Suganuma H, Suzukı M, et al Abnormal hemoglobın ( $\mathrm{Hb}$ Takamatsu) detected in routıne determınatıon of glycosylated hemoglobın by $\mathrm{HbAlc}$ automated analyzer of high performance liquid chromatography - Interference in the hemoglobin A1c fraction -. Rinsho Byorı (Japanese Journal of Clinical Pathology) 35: 297, 1987 (in Japanese).

15) Miyajıma S, Kızawa S, Asanuma H, Tomita A, Harano T, Ueda S. A case of abnormal $\mathrm{Hb}$ detected by HPLC. Rınsho Byorı (Japanese Journal of Clinical Pathology) 35: 73, 1987 (Abstract in Japanese).

16) Shiwa M, Fukuda K, Kawata Y, et al. Abnormal hemoglobin (Hb Camden) detected by interference in the determination of glycosylated hemoglobin with high performance liquid chromatography. Rınsho Byorı (Japanese Journal of Clinical Pathology) 36: 866, 1988 (in Japanese).

17) Yuya I, Imamura M, Iı K, et al. A case of diabetes mellitus with $\mathrm{Hb}$ Rayadh. Nippon Narka Gakka Zassh (Journal of the Japanese Society of Internal Medicine) 78: 1368, 1989 (in Japanese).

18) Noda M, Oka Y, Kasuga M, Kanazawa $Y$, Wada $Y$ A diabetıc case of $\mathrm{Hb}$ Riyadh with abnormally low value of HbA1c. Diabetes Journal 17: 15, 1989 (In Japanese).

19) Maezawa $Y$, Yamauchı M, Nakabayashı T, Toshıma K, Ikeda K, Toda G. A diabetic case of $\mathrm{Hb}$ Riyadh with a low HbAlc value. Intern Med 32: 128,1993

20) Harano $T$, Harano $K$, Shıbata $S$, Ueda S, Morı H, Arımasa N. Hemoglobın Okayama $\left[\beta_{2}\right.$ (NA2)His replaced by Gln]: A new 'silent' hemoglobin variant with substituted amino acid residue at the 2,3-diphosphoglycerate binding site FEBS Lett 156: 20, 1983.

21) Barwıck RC, Jones RT, Head CG, Shıh MF, Prchal JT, Shıh DT. Hb Long Island: A hemoglobin variant with a methionyl extension at the $\mathrm{NH}_{2}$ terminus and a prolyl substitution for the normal histidyl residue 2 of the $\beta$ chain Proc Natl Acad Scı USA 82: 4602, 1985.

22) Boissel JP, Kasper TJ, Shah SC, Malone JI, Bunn HF. Amıno-termunal processing of proteins: Hemoglobin South Florida, a variant with retention of initiator methionine and $\mathrm{N}^{\alpha}$-acetylation. Proc Natal Acad Sc1 USA 82: $8448,1985$.

23) Shah SC, Malone JI, Boissel JP, Kasper TJ. Hemoglobin South Florıda: New variant with normal electrophoretic pattern mistaken for glycosylated hemoglobin Diabetes 35: 1073, 1986.

24) Enokı Y, Ohga Y, Kohzukı H, Sakata S, Shımızu S. Structural and functional characterization of a $\beta$-variant hemoglobin in a Japanese dıabetıc. Nippon Seırıgaku Zasshı (J Physiol Soc Japan) 49: 529, 1987 (Abstract).

25) Blanke S, Johnsen A, Wimberley PD, Mortensen HB Hemoglobın Hafnı: $\alpha_{2}\left(\beta 116(\mathrm{G} 18) \mathrm{H}_{1 \mathrm{~s}} \rightarrow \mathrm{Gln}\right)_{2}$; A new hemoglobın varıant mistaken for glycated hemoglobin. Biochım Biophys Acta 955: 214, 1988. 